\title{
Chondroblastoma of the Clivus: Case Report and Review
}

\author{
Jonathan Liu ${ }^{1}$ Arjang Ahmadpour ${ }^{1} \quad$ Arnaud F. Bewley $^{2} \quad$ Mirna Lechpammer $^{3}$ Matthew Bobinski ${ }^{4}$ \\ Kiarash Shahlaie ${ }^{1}$
}

1 Department of Neurological Surgery, UC Davis School of Medicine, Sacramento, California, United States

${ }^{2}$ Department of Otolaryngology, UC Davis School of Medicine,

Sacramento, California, United States

${ }^{3}$ Department of Pathology, UC Davis School of Medicine, Sacramento, California, United States

${ }^{4}$ Department of Radiology, UC Davis School of Medicine, Sacramento, California, United States

Address for correspondence Kiarash Shahlaie, MD, PhD, Department of Neurological Surgery, UC Davis School of Medicine, 4860 Y Street, Suite 3740, Sacramento, CA 95817 (e-mail: krshahlaie@ucdavis.edu).

J Neurol Surg Rep 2015;76:e258-e264.

\begin{abstract}
Keywords

- chondroblastoma

- clivus

- endoscopic endonasal approach

- clival tumor

Background and Importance Chondroblastoma is a benign primary bone tumor that typically develops in the epiphyses of long bones. Chondroblastoma of the craniofacial skeleton is extremely rare, with most cases occurring in the squamosal portion of the temporal bone. In this report, we describe the first case of chondroblastoma of the clivus presenting with cranial neuropathy that was treated with endoscopic endonasal resection. We review the literature on craniofacial chondroblastomas with particular emphasis on extratemporal lesions.

Case Presentation A 27-year-old woman presented with severe headache, left facial dysesthesias, and diplopia. Physical examination revealed hypesthesia in the left maxillary nerve dermatome, and complete left abducens nerve palsy. Imaging demonstrated an expansile intraosseous mass originating in the upper clivus with extension superiorly into the sella turcica and laterally to involve the medial wall of the left cavernous sinus. The tumor was completely resected via an endoscopic endonasal approach, with postoperative improvement in lateral gaze palsy. Histopathology was consistent with chondroblastoma.

Conclusion Chondroblastoma is a rare tumor of the craniofacial skeleton that should be included in the differential diagnosis of an osteolytic lesion of the clivus. Complete surgical resection remains the mainstay of treatment.
\end{abstract}

\section{Introduction}

First described by Codman in 1931, chondroblastoma is a rare benign tumor that accounts for $1 \%$ of all primary bone neoplasms. $^{1-3}$ These lesions typically originate from chondroblasts within the epiphyses of long bones, and are most common in the proximal humerus, distal femur, or proximal tibia. ${ }^{4}$ Chondroblastoma usually presents in the second de- cade of life, with a 2:1 male predominance, and causes localized swelling and pain that is managed with surgical resection and reconstruction. ${ }^{5,6}$

Chondroblastoma of the craniofacial skeleton is particularly rare, most frequently occurring within the squamous portion of the temporal bone. ${ }^{5,7,8}$ To date, only 20 extratemporal chondroblastoma of the craniofacial skeleton have been reported, typically presenting in the third decade of life with received

January 20, 2015

accepted after revision

August 10, 2015

published online

October 9, 2015
DOI http://dx.doi.org/

10.1055/s-0035-1564601. ISSN 2193-6358. (c) 2015 Georg Thieme Verlag KG
Stuttgart · New York

License terms

$\circledast(1) \Theta \circledast$ 
local mass effect and possible cranial neuropathy. We report the first case of chondroblastoma of the clivus causing diplopia that was resected via an endoscopic endonasal approach.

\section{Case Report}

\section{Clinical History}

A 27-year-old woman with an 18-month history of headache and intermittent diplopia presented to the hospital with a 48hour history of severe headache, persistent diplopia, and left facial dysesthesias. Physical examination revealed hypesthesia in the left maxillary nerve dermatome, and complete left abducens nerve palsy with esotropia.
A computed tomography (CT) scan of the head demonstrated an expansile intraosseous mass of the upper clivus, measuring $28 \times 20 \times 19 \mathrm{~mm}$ (-Fig. 1A). The mass was relatively well circumscribed, contained multiple scattered foci of punctate calcifications, and resulted in erosion of the posterior cortex of the clivus and of the medial cortex of the carotid canal. It caused effacement of the prepontine cistern and mild narrowing of the internal carotid artery (ICA) as demonstrated by CT angiogram (-Fig. 1B).

On magnetic resonance imaging (MRI), the mass was isointense to gray matter on T1-weighted sequences, markedly hypointense on T2-weighted sequences, and diffusely but mildly enhancing after gadolinium administration (-Fig. 1C and 1D).
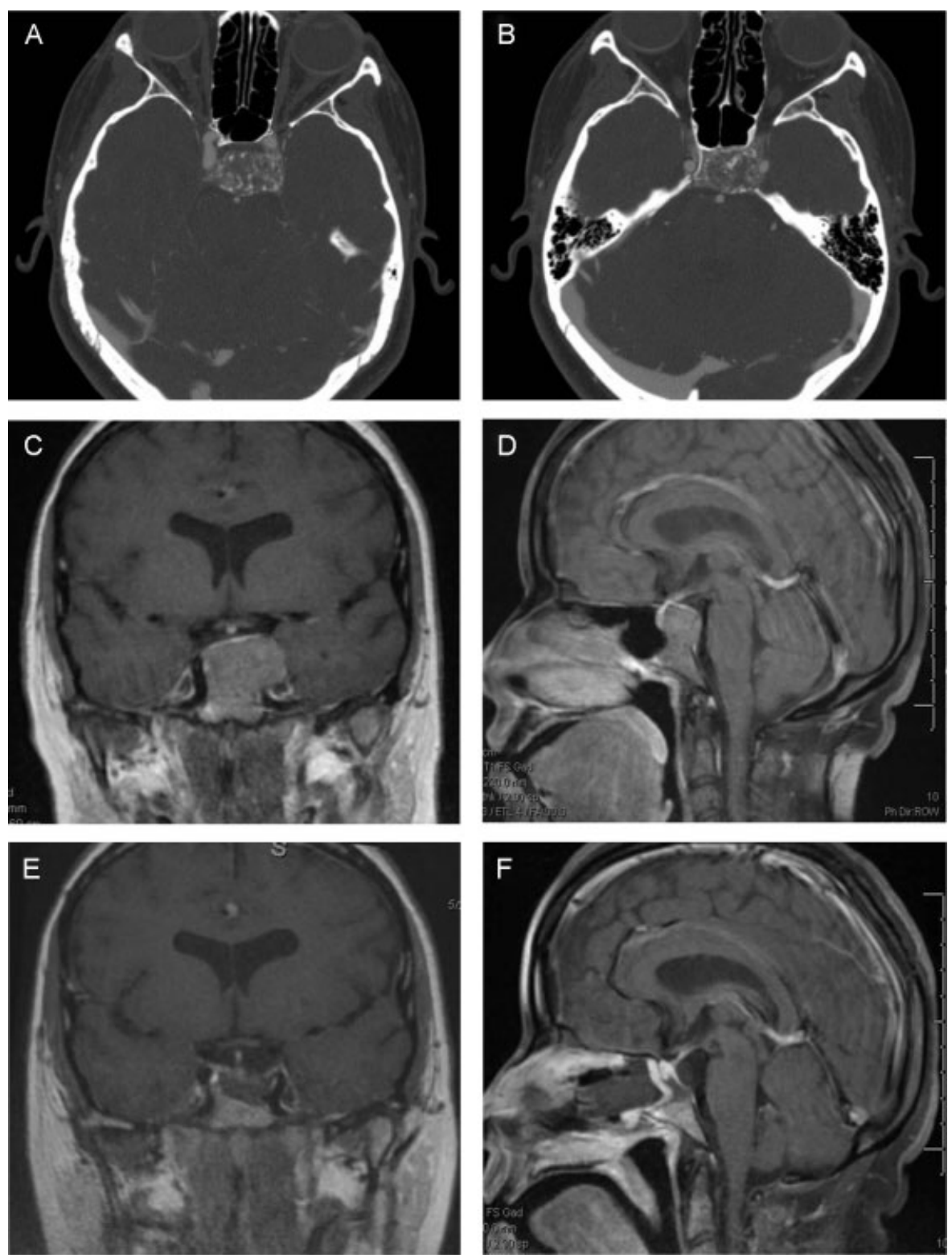

Fig. 1 Preoperative CTA demonstrating calcified expansile lesion of the upper clivus and posterior sella turcica, with compression of the left cavernous sinus (panel A) and erosion of the carotid canal along its vertical clival segment (panel B). Preoperative coronal (panel C) and sagittal (panel D) gadolinium-enhanced MRI demonstrating a homogenously enhancing expansile lesion of the middle and upper clivus with anteriosuperior deviation of the pituitary gland and compression of the left cavernous sinus. Immediate postoperative MRI scans demonstrates gross-total resection of tumor (panel E), with decompression of the pituitary gland and stalk (panel F). CTA, computed tomography angiography; MRI, magnetic resonance imaging. 
The mass extended laterally to the medial wall of the left cavernous sinus resulting in mild mass effect on the cavernous segment of the left ICA. It also eroded the floor of the sella turcica and extended into the sella and suprasellar cistern causing superoanterior deviation of the pituitary gland but no mass effect on the optic chiasm. There was mild effacement of the prepontine cistern, with encroachment on the basilar artery and with no clear involvement of the Dorello canal.

The patient received high-dose dexamethasone and was scheduled for an urgent operation.

\section{Surgery}

A direct endoscopic endonasal approach was used to perform a right middle turbinectomy, nasoseptal flap elevation, posterior septectomy, posterior ethmoidectomy, and wide sphenoidotomy. Surgical navigation was used to identify the tumor margins and confirm adequate surgical exposure. Intraoperative Doppler ultrasound and surgical navigation were also used to identify the location of the paraclival/vertical segment of each ICA before beginning the resection.

A high-speed drill and rongeurs were used to remove the anterior face and floor of the sella turcica, as well as the anterior clivus overlying the lesion. Tumor tissue was encountered within the clivus bone, which was resected in a piecemeal fashion. Tumor was found to extend through the posterior margin of the clivus, abutting but not transgressing the dura, which appeared grossly normal (-Fig. 2). Lateral extension of the tumor behind the left paraclival ICA was removed using suction and angled ring curettes. Inferior extension into the clivus was drilled out, and superior extension through the floor of the sella turcica and behind the pituitary fossa dura was resected using suction and angled ring curettes. Along the posterior floor of the sella, at the junction with the prepontine dura at the clival recess, there was a small dural defect overlying the gland where tumor had invaded some of the dura but had not extended into the pituitary gland-this was completely resected without com- plication and no visible cerebrospinal fluid (CSF) leak was present.

After completing the tumor resection, we elected to place the nasoseptal flap over the repair given the wide area of mucosal resection required for tumor access and to mitigate the risk of delayed CSF leak from the small dural defect noted above. The nasoseptal mucosal flap was secured in place using DuraSeal (Covidien Ltd., Mansfield, MA) and buttressed with a posterior nasal packing. The patient was extubated in the operating room and transferred to the intensive care unit for postoperative care.

\section{Postoperative Course}

The patient's immediate postoperative course was uncomplicated, with mild improvement in her left lateral gaze palsy. Immediate postoperative MRI scan confirmed complete removal of the tumor, with preservation of the pituitary gland and prepontine dura ( $\mathbf{- F i g}$. 1E, F). She did not demonstrate any clinical signs of pituitary dysfunction during the perioperative period. After 3 weeks of surgery, the patient continued to experience moderate sixth nerve palsy that was managed with prism lenses in her eyeglasses. The patient's diplopia and facial dysesthesias fully recovered 3 months after surgery. Adjuvant therapy was not employed since a complete excision was achieved.

\section{Histopathology}

Grossly, the lesion was red-tan with areas of granular calcifications. Microscopically, the tumor was composed of uniform round to polygonal cells with well-defined cytoplasmic borders, round to ovoid nuclei, predominantly growing in cellular sheets ( - Fig. 3A, B). There were scattered osteoclastic giant cells. Pericellular "chicken wire-like" calcifications were identified (-Fig. $3 \mathbf{C}$ ) pathognomonic of chondroblastoma.

Tumor cells were focally positive for S-100 and proliferative activity was estimated to be 5 to $10 \%$ ( - Fig. 3D). These findings were consistent with a histopathologic diagnosis of chondroblastoma.
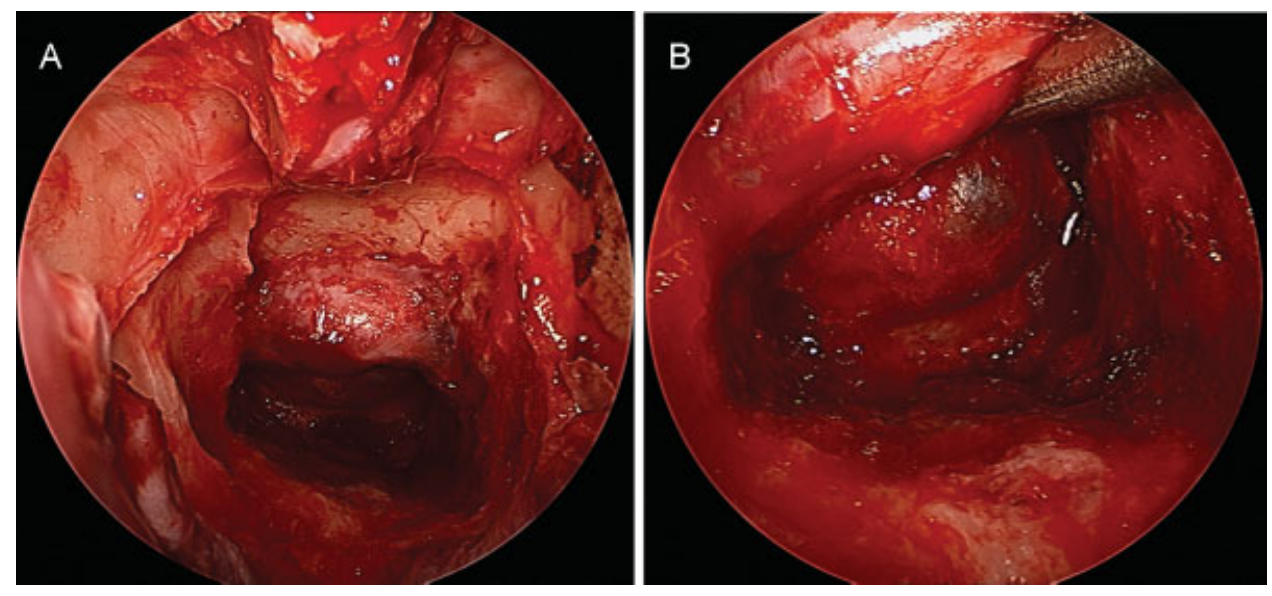

Fig. 2 Endoscopic view of the sphenoid sinus after resection of the clivus mass (panel A). The tumor occupied the middle and upper clivus, with anterior extension to, but not into, the prepontine dura (panel B). 


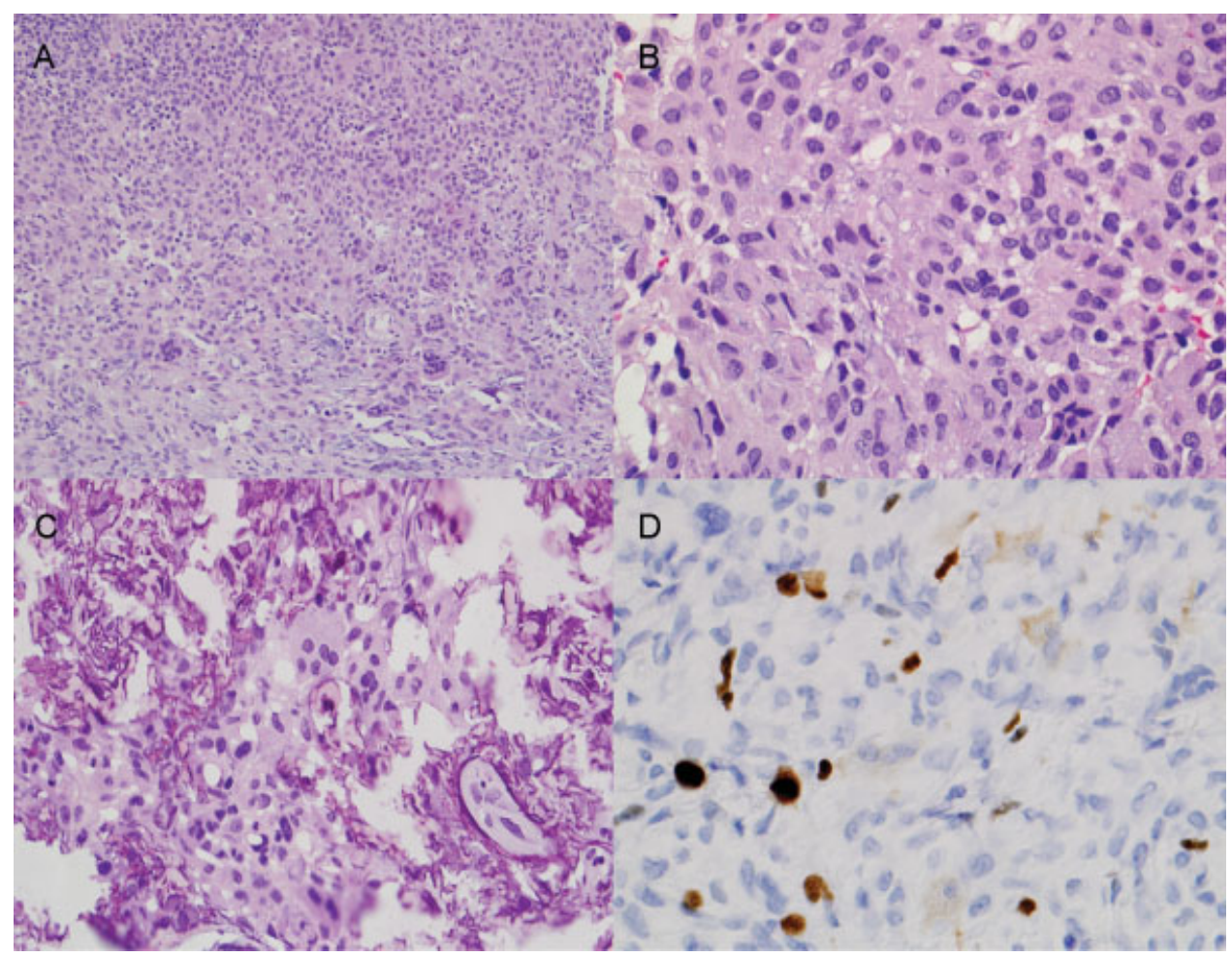

Fig. 3 (Panel A) Chondroblastoma composed of sheets of mostly uniform appearing chondroblasts and scattered osteoclast-type giant cells, H\&E, $\times 200$ magnification; (panel B) H\&E, $\times 400$ magnification; (panel C) pericellular "chicken wire" calcifications, H\&E, $\times 400$ magnification; (panel D) proliferative $\mathrm{K}_{\mathrm{i}}-67$ activity, $\times 400$ magnification. $\mathrm{H} \& \mathrm{E}$, hematoxylin and eosin.

\section{Discussion}

Chondroblastoma occurring outside of the epiphyses of long bones is rare, with lesions of the craniofacial skeleton accounting for 6.6 to $7.1 \%$ of all cases. ${ }^{1,2,9}$ The mean age of presentation is 39.4 years, significantly older than patients with long bone disease. ${ }^{5,10,11}$ Signs and symptoms of craniofacial chondroblastoma vary based on anatomic location, often resulting from mass effect on adjacent structures. For example, lesions of the temporal bone often present with hearing loss (49\%), cranial neuropathy (43.3\%), facial swelling (22.2\%), and/or otalgia (19.8\%). ${ }^{8,12-18}$ Since the abducens nerve is particularly prone to compression at the clivus where it enters the Dorello canal, ${ }^{19}$ chondroblastoma in this region can result in diplopia with lateral rectus palsy and headache.

The squamous portion of temporal bone is the most common site of craniofacial chondroblastoma, likely due to its cartilaginous origin. ${ }^{10,17,18}$ Reid et al identified 81 total reported temporal bone cases since $1950 .^{12}$ Only 24 extratemporal craniofacial lesions have been reported previously, including chondroblastoma in the region of the temporomandibular joint $(n=13)$, the nasal cavity and paranasal sinuses $(n=5)$, skull base $(n=1)$, skull vault $(n=4)$, and nasion $(n=1 \text {, see }- \text { Table } 1)^{1,6,9,20-32}$

In 1978, Harner et al postulated that chondroblastoma results from a transition incident during cartilaginous or endochondral bone formation. ${ }^{33}$ In 1992, Varvares et al further theorized that chondroblastomas arise from normal chondrocytes that transform in response to an alteration in the local environment. ${ }^{34}$ For example, such an initiating event can occur when normal mesenchymal or cartilaginous tissue is trapped within the petrosquamous suture line during temporal bone development. ${ }^{35,36}$ The petrosquamous suture delineates the embryologically distinct squamous and petrous portions of the temporal bone, making this theory plausible. ${ }^{35}$ Expanding on the above theory, it is possible that chondroblastoma of the clivus originates from the cartilaginous union of the sphenoid body and basilar part of the occipital bone, or from cells trapped within the sphenooccipital synchondrosis. $^{37}$

The three hallmark histopathological features of chondroblastoma are mononuclear cells (chondroblasts), osteoclasticlike giant cells, and a chondromyxoid stroma surrounding neoplastic cells. ${ }^{12,38,39}$ In general, chondroblastomas display low proliferative activity. ${ }^{18,40}$ High mitotic activity, however, has been described by Ishikawa et al in an aggressively growing temporal bone chondroblastoma with a high MIB1 index. $^{40}$

Chondroblastoma must be differentiated from other giant cell tumors. The osteoclastic-like giant cells seen in chondroblastomas can have striking histological similarities to giant cell reparative granulomas, aneurysmal bone cysts, giant cell tumors, and chondromyxoid fibromas. Positive staining for S100 is most commonly used to help differentiate from other giant cell tumors, since this protein is expressed on human chondrocytes and related to chondroid tissue formation. ${ }^{22,41}$

Radiographically, chondroblastoma of the long bone presents as a well-demarcated, round-to-ovoid lytic lesion, 
e262 Chondroblastoma of the Clivus: Case Report and Review Liu et al.

Table 1 Summary of extratemporal craniofacial chondroblastoma case reports

\begin{tabular}{|c|c|c|c|c|c|c|c|c|}
\hline Authors and year & $\begin{array}{l}\text { Location } \\
\text { of mass }\end{array}$ & $\begin{array}{l}\text { Age } \\
\text { (y), } \\
\text { sex }\end{array}$ & Presentation & Management & $\begin{array}{l}\text { Radiographic } \\
\text { evidence of } \\
\text { growth }\end{array}$ & $\begin{array}{l}\text { Symptom } \\
\text { duration }\end{array}$ & $\begin{array}{l}\text { Follow- } \\
\text { up } \\
\text { (mo) }\end{array}$ & Outcome \\
\hline $\begin{array}{l}\text { Lee et al, } \\
1976\end{array}$ & $\begin{array}{l}\text { Anterior } \\
\text { clinoid }\end{array}$ & $13, \mathrm{M}$ & $\begin{array}{l}\text { Headache, } \\
\text { oculomotor } \\
\text { nerve palsy }\end{array}$ & $\begin{array}{l}\text { Surgical } \\
\text { resection }\end{array}$ & Yes & $2 y$ & NR & NR \\
\hline $\begin{array}{l}\text { Al-Dewachi et al, } \\
1980\end{array}$ & Maxilla & $13, \mathrm{~F}$ & Painless mass & $\begin{array}{l}\text { Surgical } \\
\text { resection }\end{array}$ & Yes & $4 \mathrm{mo}$ & 8 & NED \\
\hline $\begin{array}{l}\text { Badia et al, } \\
1985\end{array}$ & Maxilla & $17, \mathrm{~F}$ & NR & $\begin{array}{l}\text { Surgical } \\
\text { resection }\end{array}$ & Yes & NR & 6 & NED \\
\hline $\begin{array}{l}\text { Martinez-Madrigal } \\
\text { et al, } 1991\end{array}$ & Maxilla & $14, F$ & $\begin{array}{l}\text { Nasal } \\
\text { obstruction, } \\
\text { epistaxis, } \\
\text { exophthalmos }\end{array}$ & $\begin{array}{l}\text { Surgical } \\
\text { resection }\end{array}$ & Yes & $2 \mathrm{mo}$ & NR & NR \\
\hline $\begin{array}{l}\text { Burgin et al, } \\
2010\end{array}$ & $\begin{array}{l}\text { Sphenoid } \\
\text { sinus }\end{array}$ & $30, F$ & Headache & $\begin{array}{l}\text { Surgical } \\
\text { resection } \\
\text { (endonasal) }\end{array}$ & Yes & NR & 6 & $\begin{array}{l}\text { Tumor } \\
\text { left } \\
\text { on ICA }\end{array}$ \\
\hline $\begin{array}{l}\text { Cabrera et al, } \\
2006\end{array}$ & TMJ region & $31, M$ & $\begin{array}{l}\text { Swelling over } \\
\text { preauricular } \\
\text { area }\end{array}$ & $\begin{array}{l}\text { Surgical } \\
\text { resection }\end{array}$ & Yes & $3 y$ & 12 & NED \\
\hline $\begin{array}{l}\text { Cabrera et al, } \\
2006\end{array}$ & TMJ region & $38, F$ & Painless mass & $\begin{array}{l}\text { Surgical } \\
\text { resection }\end{array}$ & Yes & $2 y$ & NR & NED \\
\hline $\begin{array}{l}\text { Ohnishi et al, } \\
1985\end{array}$ & Occiput & $14, \mathrm{M}$ & $\begin{array}{l}\text { Headache, } \\
\text { loss of } \\
\text { consciousness }\end{array}$ & $\begin{array}{l}\text { Surgical } \\
\text { resection }\end{array}$ & Yes & $1 \mathrm{~d}$ & 36 & NED \\
\hline $\begin{array}{l}\text { Araújo et al, } \\
1995\end{array}$ & Occiput & $16, \mathrm{~F}$ & $\begin{array}{l}\text { Vertigo, } \\
\text { ataxia }\end{array}$ & $\begin{array}{l}\text { Surgical } \\
\text { resection }\end{array}$ & Yes & $2 \mathrm{mo}$ & 24 & NED \\
\hline $\begin{array}{l}\text { Goodsell et al, } \\
1964\end{array}$ & Mandible & $41, M$ & $\begin{array}{l}\text { Swelling of } \\
\text { temporal } \\
\text { region }\end{array}$ & $\begin{array}{l}\text { Surgical } \\
\text { resection }\end{array}$ & Yes & $2 y$ & 32 & Recurrence \\
\hline $\begin{array}{l}\text { Milazzo et al, } \\
1967\end{array}$ & Mandible & $28, \mathrm{M}$ & $\begin{array}{l}\text { Swelling of } \\
\text { mandible }\end{array}$ & $\begin{array}{l}\text { Surgical } \\
\text { resection }\end{array}$ & No & $2 y$ & 24 & NED \\
\hline $\begin{array}{l}\text { Bertoni et al, } \\
1987\end{array}$ & Mandible & $42, \mathrm{M}$ & Pain & $\begin{array}{l}\text { Surgical } \\
\text { resection }\end{array}$ & No & $2 y$ & 156 & NED \\
\hline $\begin{array}{l}\text { Bertoni et al, } \\
1987\end{array}$ & Mandible & $58, \mathrm{M}$ & Pain & $\begin{array}{l}\text { Surgical } \\
\text { resection }\end{array}$ & No & NR & NR & NR \\
\hline $\begin{array}{l}\text { Bertoni et al, } \\
1987\end{array}$ & Mandible & $43, F$ & Swelling & $\begin{array}{l}\text { Surgical } \\
\text { resection }\end{array}$ & No & $2 y$ & NR & NR \\
\hline $\begin{array}{l}\text { Bertoni et al, } \\
1987\end{array}$ & Mandible & $37, \mathrm{M}$ & Pain & $\begin{array}{l}\text { Surgical } \\
\text { resection }\end{array}$ & No & $3 y$ & 48 & NED \\
\hline $\begin{array}{l}\text { Bertoni et al, } \\
1987\end{array}$ & Mandible & $22, \mathrm{~F}$ & NR & $\begin{array}{l}\text { Surgical } \\
\text { resection }\end{array}$ & No & NR & 44 & NED \\
\hline $\begin{array}{l}\text { Bertoni et al, } \\
1987\end{array}$ & Mandible & $44, \mathrm{M}$ & NR & $\begin{array}{l}\text { Surgical } \\
\text { resection } \\
\times 2\end{array}$ & No & NR & NR & NR \\
\hline $\begin{array}{l}\text { Bertoni et al, } \\
1987\end{array}$ & Mandible & 19, M & $\begin{array}{l}\text { Pain and } \\
\text { swelling }\end{array}$ & $\begin{array}{l}\text { Surgical } \\
\text { resection }\end{array}$ & No & $1 \mathrm{mo}$ & 2 & NED \\
\hline $\begin{array}{l}\text { Payne et al, } \\
1987\end{array}$ & Mandible & $33, F$ & Pain & $\begin{array}{l}\text { Surgical } \\
\text { resection }\end{array}$ & Yes & $3 y$ & NR & NED \\
\hline $\begin{array}{l}\text { Kondoh et al, } \\
2002\end{array}$ & Mandible & $27, \mathrm{~F}$ & $\begin{array}{l}\text { Malocclusion, } \\
\text { trismus }\end{array}$ & $\begin{array}{l}\text { Surgical } \\
\text { resection }\end{array}$ & Yes & $2 y$ & 144 & NED \\
\hline $\begin{array}{l}\text { al-Sader et al, } \\
1996\end{array}$ & $\begin{array}{l}\text { Nasal } \\
\text { bridge }\end{array}$ & $15, F$ & $\begin{array}{l}\text { Swelling over } \\
\text { nasal bridge }\end{array}$ & $\begin{array}{l}\text { Surgical } \\
\text { resection }\end{array}$ & No & NR & 12 & NED \\
\hline $\begin{array}{l}\text { Bertoni et al, } \\
1987\end{array}$ & $\begin{array}{l}\text { Parietal } \\
\text { bone }\end{array}$ & $26, F$ & Painless mass & $\begin{array}{l}\text { Surgical } \\
\text { resection }\end{array}$ & No & $7 y$ & 96 & NED \\
\hline
\end{tabular}




\begin{tabular}{|c|c|c|c|c|c|c|c|c|}
\hline Authors and year & $\begin{array}{l}\text { Location } \\
\text { of mass }\end{array}$ & $\begin{array}{l}\text { Age } \\
(y), \\
\text { sex }\end{array}$ & Presentation & Management & $\begin{array}{l}\text { Radiographic } \\
\text { evidence of } \\
\text { growth }\end{array}$ & $\begin{array}{l}\text { Symptom } \\
\text { duration }\end{array}$ & $\begin{array}{l}\text { Follow- } \\
\text { up } \\
\text { (mo) }\end{array}$ & Outcome \\
\hline $\begin{array}{l}\text { Dahlin et al, } \\
1972\end{array}$ & $\begin{array}{l}\text { Parietal } \\
\text { bone }\end{array}$ & NR & Swelling & NR & No & NR & NR & NR \\
\hline $\begin{array}{l}\text { Miyake et al, } \\
1984\end{array}$ & $\begin{array}{l}\text { Nasal } \\
\text { cavity/ } \\
\text { frontal } \\
\text { region }\end{array}$ & $1.7, \mathrm{~F}$ & Seizure & $\begin{array}{l}\text { Surgical } \\
\text { resection }\end{array}$ & Yes & NR & NR & NR \\
\hline
\end{tabular}

Abbreviations: ICA, internal carotid artery; NED, no evidence of disease; NR, not reported; TMJ, temporomandibular joint.

occasionally containing calcific foci (range, 30-50\%). ${ }^{2,22,42}$ In the temporal bone, these lesions can be solid or cystic, with an osteolytic appearance and areas of punctate calcifications (as was present in the case we present). 5,8,10,11,13,16,43

MRI findings are more variable-lesions are often low-tointermediate intensity on T1-weighted sequences and lowto-high intensity on T2-weighted MRI ${ }^{5,10}$ and demonstrate contrast enhancement, which can be peripheral, homogeneous, or heterogeneous. ${ }^{10,40,44}$ The clival lesion we present appeared intermediate intensity on T1-weighted and low intensity on T2-weighted sequences, consistent with endochondral bone formation and cartilaginous tumor matrix rather than chronic blood products. ${ }^{5}$

The differential diagnosis for an expansile clival mass, such as in our patient, includes chondrosarcoma, chordoma, plasmacytoma, and much less likely chondromyxoid fibroma. Presence of chondroid matrix excludes chordoma and plasmacytoma. Chondrosarcoma, the most frequent clival chondroid mass, cannot be reliably differentiated by imaging from chondroblastoma and chondromyxoid fibroma.

\section{Management Strategies}

Since chondroblastoma is a benign locally aggressive tumor, complete excision is the mainstay of treatment. ${ }^{12,41,45,46}$ Simple curettage is not adequate, as it has been associated with a recurrence rate of 55\%. ${ }^{2,47}$ Kurokawa et al and Moon et al found no evidence of recurrence 5 and 9 years after following complete en bloc resection of temporal bone chondroblastoma. ${ }^{46,47}$ However, some authors have reported recurrence rates approaching $20 \%$, even after complete tumor removal. $^{4,10,17}$ Therefore, surveillance imaging following surgical resection is prudent for early diagnosis of tumor recurrence.

There is insufficient data to predict tumor behavior in craniofacial chondroblastoma. Malignant degeneration to chondrosarcoma is likely rare but has been previously reported, ${ }^{11}$ and some authors have suggested that lesions with an intratumoral aneurysmal bone cyst may behave more aggressively. $^{8}$

Radiation therapy is a treatment option for poor surgical candidates, or patients with recurrent or unresectable disease. ${ }^{11,41}$ Radiation is not recommended after complete excision, due to the possibility of radiation-induced chon- drosarcoma. ${ }^{41}$ Metastatic workup is not recommended since metastatic craniofacial chondroblastoma has never been reported (in contrast, pelvic chondroblastoma may spread to the abdomen and lung). ${ }^{12,48}$ At present, there is no role for chemotherapy in the management of chondroblastomas. ${ }^{11}$

\section{Disclosures}

The authors report no conflict of interest concerning the materials or methods used in this study or the findings specified in this article.

\section{Acknowledgments}

We would like to thank Dr. Markku Miettinen, NIH/NCI, Bethesda, MD for an expert pathology opinion on this case.

\section{References}

1 Dahlin DC, Ivins JC. Benign chondroblastoma. A study of 125 cases. Cancer 1972;30(2):401-413

2 Kurt AM, Unni KK, Sim FH, McLeod RA. Chondroblastoma of bone. Hum Pathol 1989;20(10):965-976

3 Jaffe HL, Lichtenstein L. Benign Chondroblastoma of Bone: A Reinterpretation of the So-Called Calcifying or Chondromatous Giant Cell Tumor. Am J Pathol 1942;18(6):969-991

4 Hong SM, Park YK, Ro JY. Chondroblastoma of the temporal bone: a clinicopathologic study of five cases. J Korean Med Sci 1999;14(5): 559-564

5 Flowers CH, Rodriguez J, Naseem M, Reyes MM, Verano AS. MR of benign chondroblastoma of the temporal bone. AJNR Am J Neuroradiol 1995;16(2):414-416

6 Al-Dewachi HS, Al-Naib N, Sangal BC. Benign chondroblastoma of the maxilla: a case report and review of chondroblastomas in cranial bones. Br J Oral Surg 1980;18(2):150-156

7 Dran G, Niesar E, Vandenbos F, Noel G, Paquis P, Lonjon M. Chondroblastoma of the apex portion of petrousal bone. Childs Nerv Syst 2007;23(2):231-235

8 Horn KL, Hankinson H, Nagel B, Erasmus M. Surgical management of chondroblastoma of the temporal bone. Otolaryngol Head Neck Surg 1990;102(3):264-269

9 Bertoni F, Unni KK, Beabout JW, Harner SG, Dahlin DC. Chondroblastoma of the skull and facial bones. Am J Clin Pathol 1987;88(1): $1-9$

10 Hatano M, De Donato G, Falcioni M, Sanna M. Chondroblastoma of the temporal bone. Acta Otolaryngol 2011;131(8):890-895 
Liu et al.

11 Kutz JW Jr, Verma S, Tan HT, Lo WW, Slattery WH III, Friedman RA. Surgical management of skull base chondroblastoma. Laryngoscope 2007; 117(5):848-853

12 Reid LB, Wong DS, Lyons B. Chondroblastoma of the temporal bone: a case series, review, and suggested management strategy. Skull Base Rep 2011;1(2):71-82

13 Blaauw G, Prick JJ, Versteege C. Chondroblastoma of the temporal bone. Neurosurgery 1988;22(6 Pt 1):1102-1107

14 Feely M, Keohane C. Chondroblastoma of the skull. J Neurol Neurosurg Psychiatry 1984;47(12):1348-1350

15 Shek TW. Chondroblastoma of temporal bone. Am J Otol 2000; 21(4):597-598

16 Tanohata K, Noda M, Katoh H, et al. Chondroblastoma of temporal bone. Neuroradiology 1986;28(4):367-370

17 Watanabe N, Yoshida K, Shigemi H, Kurono Y, Mogi G. Temporal bone chondroblastoma. Otolaryngol Head Neck Surg 1999;121(3): 327-330

18 Bian LG, Sun QF, Zhao WG, Shen JK, Tirakotai W, Bertalanffy H. Temporal bone chondroblastoma: a review. Neuropathology 2005;25(2):159-164

19 Shono T, Mizoguchi M, Yoshimoto K, Amano T, Natori Y, Sasaki T. Clinical course of abducens nerve palsy associated with skull base tumours. Acta Neurochir (Wien) 2009;151(7):733-738, discussion 738

20 Burgin SJ, Porter RG, Mehrota S, Welch KC. Chondroblastoma of the sphenoid sinus. . Otolaryngol Head Neck Surg 2010;143(4): 591-592

21 Cabrera RA, Almeida M, Mendonça ME, Frable WJ. Diagnostic pitfalls in fine-needle aspiration cytology of temporomandibular chondroblastoma: report of two cases. Diagn Cytopathol 2006: 34(6):424-429

22 Kondoh T, Hamada Y, Kamei K, Seto K. Chondroblastoma of the mandibular condyle: report of a case. J Oral Maxillofac Surg 2002; 60(2):198-203

23 Lee KF, Whiteley WH III, Schatz NJ, Edeiken J, Lin SR, Tsai FY. Juxtasellar hyperostosis of non-meningiomatous origin. J Neurosurg 1976;44(5):571-579

24 Martinez-Madrigal F, Vanel D, Luboinski B, Terrier P. Case report 670: Chondroblastoma maxillary sinus. Skeletal Radiol 1991; 20(4):299-301

25 Ohnishi T, Oku Y, Yamamoto K, Morimura Y, Ushio Y. Benign chondroblastoma of the occipital bone. Surg Neurol 1985;24(1): 52-56

26 Badia DM, Vallogini P, Marinelli M, Agrestini C. Benign chondroblastoma localized in the maxilla [in Italian]. Stomatol Mediterr 1985;5(1):75-80

27 Araújo JF, De Castro GC, Iafigliola MG, Balbo RJ. Benign chondroblastoma of the occipital bone. A case report [in Portuguese]. Arq Neuropsiquiatr 1995;53(4):834-836

28 Goodsell JO, Hubinger HL. Benign Chondroblastoma of Mandibular Condyle: Report of Case. J Oral Surg Anesth Hosp Dent Serv 1964; 22:355-363

29 Milazzo F. On an unusual case of chondroblastoma of the mandible [in Italian]. Arch Ital Otol Rinol Laringol 1967;78(1):61-72
30 Payne M, Yusuf H. Benign chondroblastoma involving the mandibular condyle. Br J Oral Maxillofac Surg 1987;25(3):250-255

31 al-Sader MH, Tait R, Leader M. Chondroblastoma-an unusual site in a young patient. J Laryngol Otol 1996;110(7):696-699

32 Miyake H, Hashi K, Nin K, et al. Intracranial benign chondroblastoma. A case report and review of the literature [in Japanese]. No Shinkei Geka 1984;12(3, Suppl):419-425

33 Harner SG, Cody DT, Dahlin DC. Benign chondroblastoma of the temporal bone. Otolaryngol Head Neck Surg (1979) 1979;87(2): 229-236

34 Varvares MA, Cheney ML, Goodman ML, Ceisler E, Montgomery WW. Chondroblastoma of the temporal bone. Case report and literature review. Ann Otol Rhinol Laryngol 1992;101(9):763-769

35 Selesnick SH, Levine JM. Chondroblastoma of the temporal bone: consistent middle fossa involvement. Skull Base Surg 1999;9(4): 301-305

36 Chavan SS, Yenni V, Kulkarni M. Chondroblastoma of squamous part of the temporo-parietal region of skull vault: a case report and review of literature. N Am J Med Sci 2012;4(4):199-202

37 Krishan K, Kanchan T. Evaluation of spheno-occipital synchondrosis: A review of literature and considerations from forensic anthropologic point of view. J Forensic Dent Sci 2013;5(2):72-76

38 Granados R, Martín-Hita A, Rodríguez-Barbero JM, Murillo N. Fineneedle aspiration cytology of chondroblastoma of soft parts: case report and differential diagnosis with other soft tissue tumors. Diagn Cytopathol 2003;28(2):76-81

39 Fanning CV, Sneige NS, Carrasco CH, Ayala AG, Murray JA, Raymond AK. Fine needle aspiration cytology of chondroblastoma of bone. Cancer 1990;65(8):1847-1863

40 Ishikawa E, Tsuboi K, Onizawa K, et al. Chondroblastoma of the temporal base with high mitotic activity. Neurol Med Chir (Tokyo) 2002;42(11):516-520

41 Pontius A, Reder P, Ducic Y. Temporal bone chondroblastomas. Am J Otolaryngol 2003;24(6):370-373

42 Bloem JL, Mulder JD. Chondroblastoma: a clinical and radiological study of 104 cases. Skeletal Radiol 1985;14(1):1-9

43 Muntané A, Valls C, Angeles de Miquel MA, Pons LC. Chondroblastoma of the temporal bone: CT and MR appearance. AJNR Am J Neuroradiol 1993;14(1):70-71

44 Leong HK, Chong PY, Sinniah R. Temporal bone chondroblastoma: big and small. J Laryngol Otol 1994;108(12):1115-1119

45 Stapleton CJ, Walcott BP, Linskey KR, Kahle KT, Nahed BV, Asaad WF. Temporal bone chondroblastoma with secondary aneurysmal bone cyst presenting as an intracranial mass with clinical seizure activity. J Clin Neurosci 2011;18(6):857-860

46 Moon IS, Kim J, Lee HK, Lee WS. Surgical treatment and outcomes of temporal bone chondroblastoma. Eur Arch Otorhinolaryngol 2008;265(12):1447-1454

47 Kurokawa R, Uchida K, Kawase T. Surgical treatment of temporal bone chondroblastoma. Surg Neurol 2005;63(3):265-268, discussion 268

48 Lin PP, Thenappan A, Deavers MT, Lewis VO, Yasko AW. Treatment and prognosis of chondroblastoma. Clin Orthop Relat Res 2005; 438(438):103-109 